\title{
UPPER LIMB NEURODYNAMIC BILATERAL LEBIH MENURUNKAN SKOR NYERI DAN TENSION NERVUS MEDIANUS DIBANDINGKAN DENGAN UPPER LIMB NEURODYNAMIC IPSILATERAL PADA PENDERITA CERVICAL RADICULOPATHY
}

\author{
Gede Parta Kinandana ${ }^{1}$, I Ketut Suyasa ${ }^{2}$, Wahyuddin $^{3}$, Putu Astawa ${ }^{4}$ I Made Ady Wirawan ${ }^{5}$, \\ Nyoman Mangku Karmaya ${ }^{6}$ \\ ${ }^{1}$ Program Studi Magister Fisiologi Keolahragaan, Universitas Udayana, Denpasar \\ ${ }^{2,4}$ Departemen Ortopedi dan Traumatologi, Universitas Udayana, Denpasar \\ ${ }^{3}$ Fakultas Fisioterapi Universitas Esa Unggul, Jakarta \\ ${ }^{5}$ Departemen Kesehatan Masyarakat dan Kedokteran Pencegahan, Universitas Udayana \\ ${ }^{6}$ Departemen Anatomi, Universitas Udayana \\ E-mail: gd.partakinandana@gmail.com
}

\begin{abstract}
ABSTRAK
Pendahuluan: Cervical radiculopathy merupakan suatu kondisi klinis dimana terjadinya kompresi pada akar saraf yang menyebabkan perubahan fisiologis pada jaringan saraf. Tujuan Penelitian: membuktikan upper limb neurodynamic bilateral lebih menurunkan nyeri, meningkatkan range of motion (ROM) cervical, dan ekstensi elbow pada penderita cervical radiculopathy jika dibandingkan dengan neurodynamic ipsilateral. Metode: Penelitian ini merupakan penelitian eksperimental dengan rancangan pre dan post-test control group design menggunakan 24 orang sampel yang dibagi ke dalam 2 kelompok. Pada Kelompok 1 diberikan upper limb neurodynamic ipsilateral sedangkan Kelompok 2 diberikan intervensi upper limb neurodynamic bilateral. Intervensi diberikan sebanyak 12 kali. Pengukuran skor nyeri menggunakan numerical pain rating scale (NPRS) dan ROM cervical menggunakan goniometer dan tension nervus medianus diukur melalui ROM ekstensi elbow. Hasil: Perbedaan yang bermakna antara kedua kelompok didapatkan pada pengukuran skor nyeri dengan nilai $\mathrm{p}=0,000(\mathrm{p}<0,05)$ pada pengukuran nyeri diam dan saat neurodynamic testing. Perbedaan yang bermakna juga ditemukan pada pengukuran ekstensi elbow dengan nilai $\mathrm{p}=0,000(\mathrm{p}<0,05)$. Perbedaan yang tidak bermakna ditemukan pada pengukuran ROM cervical (ekstensi, rotasi, dan lateral fleksi ipsilateral) dengan nilai $\mathrm{p}=0,377 ; 0,110$; dan 0,342 secara berurutan ( $>$ > 0,05). Kesimpulan: upper limb neurodynamic bilateral lebih menurunkan skor nyeri dan menurunkan tension nervus medianus dibandingkan dengan upper limb neurodynamic ipsilateral dan tidak lebih meningkatkan ROM cervical pada penderita cervical radiculopathy.
\end{abstract}

Kata kunci: nyeri, ROM cervical, ROM ekstensi elbow, neurodynamic ipsilateral, neurodynamic bilateral, cervical radiculopathy 


\title{
BILATERAL UPPER LIMB NEURODYNAMIC IS MORE EFFECTIVE IN REDUCING PAIN SCORE AND MEDIAN NERVE TENSION COMPARED TO IPSILATERAL UPPER LIMB NEURODYNAMIC IN INDIVIDUAL WITH CERVICAL RADICULOPATHY
}

\begin{abstract}
Introduction: Cervical radiculopathy is a clinical condition in which compression of the nerve roots causes physiological changes in nerve tissue. Objective: To prove bilateral neurodynamic upper limb reduces pain, increases cervical range of motion (ROM), and elbow extension in patients with cervical radiculopathy when compared with ipsilateral neurodynamic. Method: This study was an experimental study with a pre and post-test control group design using 24 samples divided into 2 groups. In Group 1, ipsilateral upper limb neurodynamic was given while Group 2 was given bilateral upper limb neurodynamic. Interventions were given 12 times. Measurement of pain scores using the numerical pain rating scale (NPRS) and cervical ROM using a goniometer while median nerve tension was measured by ROM of elbow extension. Results: Significant differences between the two groups were obtained in the measurement of pain scores with $p=0,000(p<0,05)$ in the measurement of pain in neutral and during neurodynamic testing. A significant difference was also found in the elbow extension measurement with a $\mathrm{p}$ value $=0,000(\mathrm{p}<0,05)$. Not significant differences were found in cervical ROM measurements (extension, rotation, and lateral ipsilateral flexion) with $\mathrm{p}$ value $=0,377 ; 0,110$; and 0,342 respectively ( $>$ > 0,05). Conclusion: bilateral upper limb neurodynamic is better in decreasing pain scores and median nerve tension compared with ipsilateral upper limb neurodynamic, but is not better in improving cervical ROM in patients with cervical radiculopathy.
\end{abstract}

Keywords: pain, cervical ROM, elbow extension ROM, ipsilateral neurodynamic, bilateral neurodynamic, cervical radiculopathy

\section{PENDAHULUAN}

Cervical radiculopathy merupakan suatu kondisi klinis di mana terjadinya kompresi pada akar saraf yang melewati ruas tulang belakang cervical menyebabkan terjadinya nyeri leher dan nyeri pada lengan. ${ }^{1}$ Insiden annual cervical radiculopathy yang dilaporkan berdasarkan analisis berbasis populasi di Rochester, Minnesota adalah 107,3 per 100.000 laki-laki dan 63,5 per 100.000 perempuan per tahun. Kejadian cervical radiculopathy paling banyak terjadi pada dekade ke empat dan lima dengan usia puncak 50 hingga 54 tahun. Prevalensi terjadinya cervical radiculopathy cenderung meningkat seiring bertambahnya usia. $^{2}$
Cervical radiculopathy disebabkan oleh beberapa faktor resiko berdasarkan beberapa studi yang dilakukan pada kelompok populasi Caucasians. Beberapa faktor resiko yang paling umum di antara meliputi umur, jenis kelamin, ras kulit putih, merokok, adanya riwayat radiculopathy lumbar, riwayat operasi bagian tulang belakang lainnya, dan mengangkat beban di atas kepala. ${ }^{2} 3$ Namun hal ini juga bergantung pada penyebaran demografis dan sosial budaya yang berbeda-beda seperti pada populasi yang memerlukan aktivitas berjalan dalam jangka waktu lama dan pada medan yang berat, serta penekanan pada akar saraf. ${ }^{3}$

Perubahan degeneratif pada tulang belakang cervical dimulai dari proses degenerasi 
pada diskus intervertebralis yang menyebabkan penurunan tinggi diskus intervertebralis dan penyempitan foramen intervertebralis. Oleh karena ini, meningkatnya beban pada sendi intervertebralis yang akhirnya mengakibatkan hipertrofi facet joint yang dapat menyebabkan stenosis pada foraminal. ${ }^{3}$

Seringkali perubahan ini disertai dengan pengerasan posterior longitudinal ligament, dan flavum ligament, yang dikategorikan sebagai perubahan statis. Gerakan yang ekstrim atau kinematika abnormal dari tulang belakang leher dianggap sebagai perubahan dinamis yang dapat menyebabkan kompresi. ${ }^{2,3}$

Kompresi pada akar saraf cervical menyebabkan perubahan fisiologis pada jaringan saraf yang terlibat. Perubahan ini menyebabkan struktur jaringan saraf cenderung lebih bersifat sensitif atau terjadi proses yang dikenal sebagai sensitisasi akar saraf. Penelitian menunjukkan terjadinya sensitisasi akar saraf pada kasus kompresi akar saraf C5-C7 yang menyebabkan nyeri menjalar di sepanjang area dermatome C5, C6, dan C7.

Intervensi mobilisasi saraf dikembangkan oleh Shacklock yang bertujuan untuk meningkatkan serta mengembalikan fungsi mekanis dari struktur saraf yaitu sliding, tension, dan compression. Neurodynamic merupakan suatu pendekatan manual terapi untuk meningkatkan ekskursi saraf terhadap jaringan di sekitarnya (mechanical interface) dengan menerapkan konsep tension, sliding, dan compression pada struktur akar saraf serta saraf perifer. ${ }^{4}$ Lingkup gerak sendi serta ekskursi saraf medianus dapat ditingkatkan melalui pengaplikasian neurodynamic. ${ }^{4,5}$

Namun, pada pengaplikasian neurodynamic sering ditemukan bahwa teknik neurodynamic yang dilakukan yaitu teknik tension, dapat memicu nyeri menjalar yang dialami pasien. Hal ini disebabkan oleh karena berubahnya sifat fisiologis jaringan saraf serta kemampuan dalam menerima pembebanan mekanis pada kasus-kasus terjadinya penjempitan akar saraf. Hal ini mengakibatkan para praktisi sulit melakukan teknik neurodynamic secara tepat sehingga hasil yang diperoleh juga tidak optimal.

Hasil ini sering ditandai dengan keluhan rasa nyeri yang luar biasa oleh karena iritasi saraf yang menyebabkan saraf lebih cenderung sensitif, sehingga sulit untuk memperoleh hasil yang optimal selama dilakukan intervensi. Hal tersebut membuat beberapa peneliti mengembangkan beberapa metode untuk mengurangi tension saraf yang terjadi selama pelaksanaan intervensi dengan mempertimbangkan anatomi dan biomekanik dari struktur saraf, salah satunya adalah dengan memberikan neurodynamic pada sisi kontralateral atau yang dapat disebut dengan bilateral neurodynamic. Masih sedikitnya bukti yang menyatakan manfaat dari neurodynamic bilateral dan masih sedikitnya pengaplikasian neurodynamic bilateral tersebut yang menjadi dasar untuk peneliti mengajukan penelitian tersebut.

\section{METODE PENELITIAN}

Penelitian ini adalah penelitian eksperimental dengan rancangan penelitian prepost control group design. Kelompok Kontrol (Kelompok 1) yaitu kelompok yang diberi intervensi upper limb neurodynamic ipsilateral. Kelompok Perlakuan (Kelompok 2) yaitu kelompok yang diberikan intervensi upper limb neurodynamic bilateral.

Adapun parameter yang diukur adalah skor nyeri menggunakan Numerical Pain Rating Scale (NPRS), ROM cervical dengan goniometer, dan tension nervus medianus dengan ROM ekstensi elbow yang dilakukan sebelum dan setelah diberikan intervensi sebanyak 12 kali untuk mengetahui hasil post-test.

Penelitian dilakukan di Praktek Fisioterapi Darmayasa, Denpasar serta Praktek Fisioterapi TBS 5, Denpasar, terhitung pada bulan Februari sampai Juni 2019 


\section{HASIL PENELITIAN}

\section{Tabel 1. Katakteristik Sampel}

\begin{tabular}{lcc}
\hline \multicolumn{1}{c}{ Karkteristik } & Kel. 1 & Kel. 2 \\
\hline $\begin{array}{l}\text { Jenis Kelamin } \\
(\%)\end{array}$ & & \\
Laki-Laki & $7(58,3)$ & $8(66,7)$ \\
Perempuan & $5(41,7)$ & $4(33,3)$ \\
Usia (tahun) & & \\
Mean \pm SD & 54,58 & $54,67 \pm 1,614$ \\
IMT $(\%)$ & $\pm 1,881$ & \\
$\quad$ Normal & $9(75,0)$ & $8(66,7)$ \\
Overweight & $3(25,0)$ & $4(33,3)$ \\
\hline
\end{tabular}

Berdasarkan Tabel 1 menunjukkan bahwa pada Kelompok 1, sampel yang berjenis kelamin laki-laki sebanyak 7 orang $(58,3 \%)$ dan perempuan sebanyak 5 orang $(41,7 \%)$. Pada Kelompok 2, sampel yang berjenis kelamin lakilaki sebanyak 8 orang $(66,7 \%)$ dan perempuan sebanyak 4 orang $(33,3 \%)$. Kelompok 1 memiliki rerata umur 54,58 $\pm 1,881$ sedangkan pada

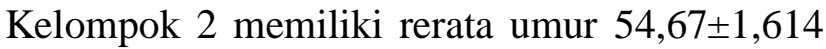
tahun Data deskriptif juga menunjukkan pada Kelompok 1, sampel yang memiliki IMT normal sebanyak $9(75,0 \%)$ dan IMT overweight sebanyak 3 orang $(25,0 \%)$. Pada Kelompok 2, sampel yang memiliki IMT normal sebanyak 8 $(66,7 \%)$ dan IMT overweight sebanyak 4 orang $(33,3 \%)$.

\section{Tabel 2. Uji Normalitas dan Homogenitas}

\begin{tabular}{|c|c|c|c|c|c|}
\hline \multirow{3}{*}{ Kelompok Data } & \multicolumn{4}{|c|}{ Uji Normalitas dengan Shapiro Wilk Test } & \multirow{3}{*}{$\begin{array}{l}\text { Uji Homogenitas } \\
\text { (Levene's Test) }\end{array}$} \\
\hline & \multicolumn{2}{|c|}{ Kelompok 1} & \multicolumn{2}{|c|}{ Kelompok 2} & \\
\hline & Statistik & p-value & Statistik & p-value & \\
\hline $\begin{array}{l}\text { ROM Ekstensi } \\
\text { Pre-Int }\end{array}$ & 0,963 & 0,820 & 0,965 & 0,853 & 0,974 \\
\hline $\begin{array}{l}\text { ROM Lat.Fleksi Ipsi } \\
\text { Pre-Int }\end{array}$ & 0,929 & 0,370 & 0,895 & 0,137 & 0,182 \\
\hline $\begin{array}{l}\text { ROM Rotasi Ipsi } \\
\text { Pre-Int }\end{array}$ & 0,867 & 0,60 & 0,946 & 0,574 & 0,056 \\
\hline $\begin{array}{l}\text { ROM Ekstensi } \\
\text { Post-Int }\end{array}$ & 0,863 & 0,53 & 0,892 & 0,124 & 0,056 \\
\hline $\begin{array}{l}\text { ROM Lat.Fleksi Ipsi } \\
\text { Post-Int }\end{array}$ & 0,957 & 0,738 & 0,936 & 0,449 & 0,751 \\
\hline $\begin{array}{l}\text { ROM Rotasi Ipsi } \\
\text { Post-Int }\end{array}$ & 0,962 & 0,811 & 0,934 & 0,811 & 0,265 \\
\hline $\begin{array}{l}\text { NPRS Diam } \\
\text { Pre-Int }\end{array}$ & 0,886 & 0,106 & 0,875 & 0,077 & 0,933 \\
\hline $\begin{array}{c}\text { NPRS ND-Testing } \\
\text { Pre-Int }\end{array}$ & 0,886 & 0,106 & 0,875 & 0,077 & 0,933 \\
\hline $\begin{array}{l}\text { NPRS Diam } \\
\text { Post-Int }\end{array}$ & 0,875 & 0,077 & 0,841 & 0,106 & 1,000 \\
\hline $\begin{array}{c}\text { NPRS ND-Testing } \\
\text { Post-Int }\end{array}$ & 0,875 & 0,077 & 0,886 & 0,106 & 0,933 \\
\hline $\begin{array}{l}\text { ROM Ekstensi Elbow } \\
\text { Pre-Int }\end{array}$ & 0,932 & 0,404 & 0,911 & 0,217 & 0,933 \\
\hline $\begin{array}{c}\text { ROM Ekstensi Elbow } \\
\text { Post-Int }\end{array}$ & 0,886 & 0,105 & 0,900 & 0,156 & 0,459 \\
\hline
\end{tabular}


Tabel 2 menunjukkan hasil uji normalitas dengan menggunakan Shapiro Wilk test didapatkan nilai probabilitas untuk kelompok data sebelum intervensi pada Kelompok 1 dimana p-value pada ketiga parameter pengukuran didapatkan sebesar $>0,05$ baik sebelum dan setelah intervensi. Sedangkan pada Kelompok 2, $p$-value pada ketiga parameter pengukuran juga didapatkan sebesar $>0,05$ baik sebelum dan setelah intervensi. Hasil tersebut menunjukkan bahwa Kelompok 1 dan Kelompok 2 memiliki data yang berdistribusi normal.
Pada uji homogenitas menggunakan Levene's test didapatkan $p$-value $>0,05$ untuk pengukuran ROM cervical, ekstensi elbow, serta nilai NPRS sebelum dan sesudah intervensi. Hal ini menunjukkan bahwa data sebelum maupun sesudah intervensi memiliki data yang homogen. Berdasarkan hasil uji normalitas dan uji homogenitas, maka uji yang digunakan untuk pengujian hipotesis adalah uji statistik parametrik.

Tabel 3. Hasil Uji Paired T-test dan Independent T-Test pada Skor Nyeri

\begin{tabular}{ccccccc}
\hline Pengukuran & Kel. & Pre & Post & Selisih & $\begin{array}{c}\text { Paired t- } \\
\text { test } \\
(p \text {-value })\end{array}$ & $\begin{array}{c}\text { Independent } \\
\text { t-test } \\
(p \text {-value })^{*}\end{array}$ \\
\hline \multirow{2}{*}{ NPRS Diam } & Kel.1 & $4,50 \pm 0,798$ & $2,58 \pm 0,793$ & $1,92 \pm 0,289$ & 0,000 & 0,000 \\
& Kel.2 & $4,42 \pm 0,793$ & $1,50 \pm 0,798$ & $2,92 \pm 0,289$ & 0,000 & \\
NPRS ND- & Kel.1 & $7,50 \pm 0,798$ & $5,42 \pm 0,798$ & $2,08 \pm 0,793$ & 0,000 & 0,000 \\
Testing & Kel.2 & $7,42 \pm 0,793$ & $2,50 \pm 0,798$ & $4,92 \pm 1,165$ & 0,000 & \\
\hline
\end{tabular}

Tabel 3 menunjukkan hasil paired t-test pada pengukuran skor nyeri menggunakan NPRS. Pada pengukuran nyeri diam setelah intervensi diperoleh $p$-value $=0,000(\mathrm{p}<0,05)$ dan pada pengukuran nyeri pada saat dilakukan neurodynamic testing setelah intervensi diperoleh p-value $=0,000(\mathrm{p}<0,05)$

Pada Kelompok 1 yang diberikan ipsilateral neurodynamic, didapatkan rerata penurunan tingkat nyeri yang diukur menggunakan NPRS setelah intervensi yaitu 2,58 $\pm 0,793$ pada nyeri diam dan $5,42 \pm 0,798$ pada nyeri saat neurodynamic testing. Sedangkan Kelompok 2 yang mendapatkan intervensi bilateral neurodynamic didapatkan penurunan tingkat nyeri setelah intervensi menjadi $1,50 \pm 0,798$ pada nyeri diam dan 2,50 $\pm 0,798$ pada nyeri saat neurodynamic testing.

Hasil analisis statistik menggunakan independent $t$-test, menunjukkan bahwa terdapat perbedaan yang signifikan antara kedua kelompok pada selisih pengukuran nyeri sebelum dan setelah intervensi yang diukur menggunakan NPRS dengan $p$-value $=0,000(1,92 \pm 0,289$ pada Kelompok 1 dan 2,92 $\pm 0,289$ pada Kelompok 2) pada pengukuran nyeri diam, dan $p$-value $=0,000$ $(2,08 \pm 0,793$ pada Kelompok 1 dan 4,92 $\pm 1,165$ pada Kelompok 2) pada nyeri saat dilakukan neurodynamic testing.

Tabel 4 memperlihatkan hasil paired $t$ test peningkatan ROM cervical yang diukur menggunakan goniometer. Didapatkan rerata selisih peningkatan ROM pada gerakan ekstensi, lateral fleksi serta rotasi ipsilateral adalah sebesar $10,75 \pm 1,138 ; 9,83 \pm 1,850 ;$ serta $10,08 \pm 0,996$ pada Kelompok 1 dan peningkatan ROM sebesar $9,83 \pm 1,850 ; 10,75 \pm 0,622 ;$ dan $10,08 \pm 0,669$ derajat pada pada gerakan ekstensi, lateral fleksi, dan rotasi ipsilateral secara berurutan pada Kelompok 2.

Hasil analisis statistik menggunakan independent t-test menunjukkan bahwa tidak terdapat perbedaan yang bermakna antara kedua kelompok pada pengukuran selisih ROM cervical 
sebelum dan setelah perlakuan pada gerakan ekstensi, lateral fleksi, dan rotasi ipsilateral dengan $p$-value $=1,58 ; 0,067 ; 1,000$ secara berurutan $(\mathrm{p}>0,05)$.

\begin{abstract}
Berdasarkan Tabel 5 yang memperlihatkan hasil paired t-test pada pengukuran ROM ekstensi elbow, diperoleh $p$ value $=0,000(\mathrm{p}<0,05)$ pada hasil pengukuran setelah perlakuan.
\end{abstract}

Tabel 4. Hasil Uji Paired T-test dan Independent T-Test pada ROM Cervical

\begin{tabular}{ccccccc}
\hline Pengukuran & Kel. & Pre & Post & Selisih & $\begin{array}{c}\text { Paired t-test } \\
(p \text {-value })\end{array}$ & $\begin{array}{c}\text { Independent } \text {-test } \\
(p \text {-value })^{*}\end{array}$ \\
\hline ROM & Kel.1 & $26,75 \pm 1,657$ & $37,50 \pm 1,446$ & $10,75 \pm 1,138$ & 0,000 & 1,58 \\
Ekstensi & Kel.2 & $26,92 \pm 1,730$ & $36,75 \pm 2,491$ & $9,83 \pm 1,850$ & 0,000 & \\
ROM & Kel.1 & $14,42 \pm 1,443$ & $24,25 \pm 1,422$ & $9,83 \pm 1,850$ & 0,000 & 0,067 \\
Lat.fleksi & Kel.2 & $14,42 \pm 0,996$ & $25,17 \pm 1,267$ & $10,75 \pm 0,622$ & 0,000 & \\
ROM & Kel.1 & $24,50 \pm 1,446$ & $34,58 \pm 1,379$ & $10,08 \pm 0,996$ & 0,000 & 1,000 \\
Rotasi & Kel.2 & $23,75 \pm 2,379$ & $33,83 \pm 2,290$ & $10,08 \pm 0,669$ & 0,000 & \\
\hline
\end{tabular}

Tabel 5. Hasil Uji Paired T-test dan Independent T-Test pada ROM Ekstensi Elbow

\begin{tabular}{ccccccc}
\hline Pengukuran & Kel. & Pre & Post & Selisih & $\begin{array}{c}\text { Paired t- } \\
\text { test } \\
(p \text {-value })\end{array}$ & $\begin{array}{c}\text { Independent } \\
\text { t-test }\end{array}$ \\
\hline ROMalue $)$ & \\
Elbow & Kel.2 & $42,00 \pm 2,296$ & $78,50 \pm 1,168$ & $36,50 \pm 2,431$ & 0,000 & 0,000 \\
\hline
\end{tabular}

Hasil analisis statistik menggunakan independent $t$-test, menunjukkan bahwa terdapat perbedaan yang bermakna antara kedua kelompok pada selisih peningkatan ROM ekstensi elbow sebelum dan setelah perlakuan yang dengan $p$-value $=0,000(16,25 \pm 1,357$ pada Kelompok 1 dan 36,50 $\pm 2,431$ pada Kelompok 2).

\section{PEMBAHASAN}

\section{Karakteristik Sampel}

Berdasarkan hasil penelitian ini, karakteristik jenis kelamin sampel pada Kelompok 1 dan Kelompok 2 terdapat perbedaan. Jumlah sampel yang berjenis kelamin laki-laki berjumlah 7 orang $(58,3 \%)$ dan perempuan sebanyak 5 orang $(41,7 \%)$. Pada Kelompok 2, sampel yang berjenis kelamin laki-laki sebanyak
8 orang $(66,7 \%)$ dan perempuan sebanyak 4 orang $(33,3 \%)$. Hal ini menunjukkan bahwa angka kejadian cervical radiculopathy lebih banyak terjadi pada laki-laki dibandingkan dengan perempuan. Data ini sesuai dengan hasil studi epidemiologi yang dilakukan di Rochester, Minnnesota, yang menunjukkan angka kejadian cervical radiculopathy yang terjadi sebesar 107,3 per 100.000 laki-laki dan 63,5 per 100.000 perempuan per tahun. $^{2}$

Dilihat dari karakteristik umur sampel, Kelompok 1 memiliki rerata umur $(54,58 \pm 1,881)$ tahun dan Kelompok 2 memiliki rerata umur $(54,67 \pm 1,614)$ tahun. Hal ini menunjukkan bahwa cervical radiculopathy lebih beresiko pada kelompok lanjut. Iyer dan Kim mendukung data deskriptif melalui hasil penelitiannya yang menunjukkan bahwa usia insiden cervical radiculopathy paling banyak terjadi pada dekade keempat dan kelima dengan usia puncak 50 
hingga 54 tahun. $^{2}$ Kejadian cervical radiculopathy cenderung meningkat seiring bertambahnya usia disebabkan oleh karena terjadi proses degeneratif pada tulang belakang cervical yang menyebabkan menipisnya tinggi diskus dan meningkatnya pembebanan pada facet articularis dan menurunnya ruang foraminal intervertebralis. Selain itu, sebuah studi retrospektif klinis pada 1305 kasus cervical radiculopathy dari tahun 2000 hingga 2010 menunjukkan bahwa sebanyak 659 kasus terjadi pada laki-laki dan sebanyak 646 kasus terjadi pada perempuan. Jika dilihat dari segi usia, sebanyak 163 kasus terjadi pada usia <40 tahun, 957 kasus terjadi pada kelompok usia 40-60 tahun, dan 185 kasus terjadi pada kelompok usia $>60$ tahun. $^{6}$

Berdasarkan IMT, terdapat sedikit perbedaan pada Kelompok 1 dan Kelompok 2. Pada Kelompok 1, jumlah sampel yang memiliki IMT normal sebanyak 9 orang $(75,0 \%)$, sedangkan yang memiliki IMT overweight sebanyak 3 orang $(25,0 \%)$, dan pada Kelompok 2 sampel yang memiliki IMT normal sebanyak 8 $(66,7 \%)$ dan IMT overweight sebanyak 4 orang $(33,3 \%)$. Peningkatan IMT tidak terlalu mempengaruhi angka kejadian cervical radiculopathy. Dalam penelitiannya terdahulu, dinyatakan bahwa angka kejadian cervical radiculopathy lebih berpengaruh pada proses degeneratif yang terjadi secara perlahan. ${ }^{2,7}$

Temuan oleh Sheng juga mendukung penelitian ini yang menunjukkan bahwa tidak adanya hubungan yang bermakna antara overweight dan obesitas dengan gangguan pada cervical (Overweight: logged odds $=-0,116, p=$ 0,304; Obese: logged odds $=-0,160, p=$ $0,865){ }^{8}$

Upper Limb Neurodynamic Bilateral Lebih Menurunkan Skor Nyeri dibandingkan dengan Upper Limb Neurodynamic Ipsilateral pada Penderita Cervical Radiculopathy

Dalam penelitian, didapatkan hasil yang menunjukkan bahwa terdapat perbedaan yang bermakna terhadap penurunan tingkat nyeri yang diukur menggunakan NPRS, baik saat nyeri diam maupun saat dilakukan neurodynamic testing dimana upper limb neurodynamic bilateral lebih menurunkan skor nyeri dibandingkan dengan upper limb neurodynamic ipsilateral.

Hasil penelitian ini didukung oleh hasil penelitian yang dilakukan oleh Salian et al yang membuktikan efektivitas dari upper limb neurodynamic pada sisi kontralateral pada penderita cervical radiculopathy. Menggunakan 30 sampel pasien yang terdiagnosis cervical radiculopathy, tingkat nyeri yang diukur dengan VAS mengalami penurunan yang signifikan $(6,47 \pm 2,21$ menjadi $1,53 \pm 1,98$ dengan $p=0,000)$ setelah pemberian intervensi sebanyak 6 kali. ${ }^{9}$ Salian mengungkapkan bahwa pemberian neurodynamic pada sisi kontralateral mengurangi iritasi pada sisi ipsilateral sehingga mengurangi sensasi nyeri yang dikeluhkan pasien selama pemberian maneuver. ${ }^{9}$

Tidak banyak studi yang membandingkan secara langsung antara upper limb neurodynamic ipsilateral dan bilateral terhadap pengaruhnya pada nyeri, namun, Lohman et al dalam studi nya menunjukkan terjadinya peningkatan strain yang signifikan pada akar saraf C5-C8 dari 6,8\% menjadi $11,87 \%$ pada saat dilakukannya upper limb neurodynamic ipsilateral. Peningkatan strain tersebut diasosiasikan dengan meningkatnya keluhan nyeri yang dialami pasien. Data terkait dengan peningkatan strain tersebut memiliki dampak langsung terhadap evidence based clinical reasoning terkait dengan pemilihan teknik intervensi pada kasus-kasus yang melibatkan akar saraf. ${ }^{10}$

Terkait dengan peningkatan strain tersebut, Rade et al melalui studi anatomi nya, mengevaluasi pergeseran ke arah distal pada medula spinalis melalui maneuver straight leg raise (SLR) menggunakan pencitraan MRI. Dalam penelitian tersebut, ditemukan bahwa bilateral SLR menghasilkan pergerseran ke arah distal 4,8 $\pm 1,48 \mathrm{~mm}$ jika dibandingkan dengan unilateral SLR yang hanya menghasilkan pergeseran sebesar 2,31 $\pm 1,22 \mathrm{~mm}$ pada medula spinalis. Rade kemudian menyimpulkan bahwa 
pergeseran medula spinalis ke arah distal ini dipercaya mengurangi ketegangan pada akar saraf yang menghasilkan penurunan nyeri yang dikeluhkan pasien. ${ }^{11}$

Baik ipsilateral maupun bilateral neurodynamic pada dasarnya terbukti dapat menurunkan tingkat nyeri yang dikeluhkan oleh pasien, namun secara statistik, besarnya penurunan nyeri tersebut memiliki kebermaknaan yang berbeda. Beberapa penelitian menunjukkan bahwa pemberian mobilisasi saraf (upper limb neurodynamic) secara ipsilateral juga dapat secara signifikan mengurangi nyeri menjalar yang dikeluhkan pada pasien yang terdiagnosis mengalami cervical radiculopathy setelah 4 hingga 8 minggu pemberian intervensi tanpa disertai dengan efek samping yang berbahaya. ${ }^{12}$, 13, 14 Namun ketika dibandingkan, upper limb neurodynamic bilateral terbukti lebih menurunkan tingkat nyeri dibandingkan dengan upper limb neurodynamic ipsilateral.

Pada pengaplikasian neurodynamic dalam intervensi pada kasus-kasus penjepitan akar saraf, sering ditemukan bahwa teknik neurodynamic yang dilakukan yaitu teknik tension yang utamanya dilakukan pada satu sisi (ipsilateral), dapat memicu nyeri menjalar yang dialami pasien. Hal ini disebabkan oleh karena berubahnya sifat fisiologis jaringan saraf serta kemampuan dalam menerima pembebanan mekanis pada kasus-kasus terjadinya penjempitan akar saraf.

Menurut pandangan peneliti, pemberian upper limb neurodynamic bilateral lebih menurunkan nyeri dibandingkan dengan upper limb neurodynamic ipsilaterl disebabkan oleh karena meningkatnya sifat viscoelastic struktur saraf oleh karena gerakan tension yang terjadi pada struktur saraf selama pemberian upper limb neurodynamic bilateral tanpa menyebabkan strain yang berlebihan yang cenderung memprovokasi sensasi nyeri pada pasien yang cenderung dirasakan saat pemberian upper limb neurodynamic pada satu sisi. Hal tersebut juga sesuai dengan teori neudoynamic contralateral yang dikemukakan oleh Shacklock dalam bukunya. $^{4}$

Dalam seting klinis, pemberian neurodynamic merupakan pilihan yang disarankan untuk mengurangi nyeri pada kasus cervical radiculopathy. Pemberian upper limb neurodynamic bilateral lebih disarankan terutama pada kondisi akut karena terbukti lebih signifikan dalam menurunkan nyeri. Memposisikan lengan pada sisi kontralateral mempengaruhi perubahan besaran strain yang terjadi pada akar saraf sehingga mempengaruhi nyeri yang dirasakan oleh pasien selama pemberian intervensi neurodynamic.

Maka dari itu, dapat disimpulkan bahwa upper limb neurodynamic bilateral lebih menurunkan skor nyeri dibandingkan dengan upper limb neurodynamic ipsilateral pada kasus cervical radiculopathy.

\section{Upper Limb Neurodynamic Bilateral Tidak Lebih Meningkatkan ROM Cervical dibandingkan dengan Upper Limb Neurodynamic Ipsilateral pada Penderita Cervical Radiculopathy}

Berdasarkan hasil uji statistik dalam penelitian ini menunjukkan bahwa tidak terdapat perbedaan yang bermakna pada ROM cervical dalam gerakan ektensi, lateral fleksi dan rotasi ipsilateral antara kelompok yang mendapatkan upper limb neurodynamic bilateral dengan upper limb neurodynamic ipsilateral pada kasus cervical radiculopathy.

Dalam penelitian ini, menggunakan uji paired t-test, ditemukan bahwa terdapat perbedaan yang signifikan pada ROM cervical sebelum dan setelah pemberian intervesi pada masing-masing kelompok. Hal ini didukung oleh penelitian yang dilakukan oleh Savva et al, dalam studinya menggunakan 42 sampel cervical radiculopathy (21 sampel mendapatkan mobilisasi saraf dan 21 sampel mendapatkan intervensi konvensional) menunjukkan bahwa terdapat peningkatan yang signifikan pada ROM cervical ke arah fleksi $(\mathrm{p}=0,039)$, lateral fleksi kontralateral $(0,024)$ dan ipsilateral $(0,012$, serta 
rotasi kontralateral $(\mathrm{p}=0,005)$ dan ipsilateral $(0,02)$ dan peningkatan yang kurang signifikan pada ekstensi cervical $(\mathrm{p}=0,072) .{ }^{15}$

Namun hasil penelitian ini bertolak belakang dengan studi eksperimental yang dilakukan oleh Salian yang membuktikan efektivitas pemberian neurodynamic pada sisi kontralateral pada 30 sampel asimptomatis yang terdiagnosis dengan cervical radiculopathy. ${ }^{9}$ Dalam penelitiannya menunjukkan bahwa terjadinya peningkatan ROM cervical ke arah fleksi, ekstensi, lateral fleksi, serta rotasi kanan dan kiri yang signifikan $(\mathrm{p}<0,05)$ sebelum dan setelah intervensi upper limb neurodynamic kontralateral jika dibandingkan dengan neurodynamic ipsilateral saja. ${ }^{9}$ Hasil bertolak belakang ini mungkin disebabkan oleh penggunaan kriteria sampel yang berbeda dimana sampel dalam penelitian oleh Salian ini adalah sampel yang terdiagnosis cervical radiculopathy namun bersifat asimptomatis. Di samping itu, rentang usia terbanyak dalam penelitian ini adalah 30 sampai 42 tahun yang juga berpotensi mempengaruhi tingkat keparahan suatu penyakit tersebut.

Belum banyak penelitian yang dapat mendukung maupun menyangkal hasil penelitian ini karena masih sedikitnya jumlah literatur dan studi yang secara langsung membuktikan efektivitas dari pemberian upper limb neurodynamic bilateral terhadap peningkatan ROM pada kondisi cervical radiculopathy dan membandingkannya dengan upper limb neurodynamic ipsilateral. Pada kondisi cervical radiculopathy, keterbatasan ROM cervical disebabkan oleh nyeri radikular yang timbul selama gerakan. Utamanya, ROM yang paling terbatas adalah lateral fleksi ipsilateral serta ekstensi cervical. Ekstensi dan lateral fleksi ipsilateral ini menyebabkan menurunnya ruang foramen intervertebral tempat keluarnya akar saraf sehingga menghasilkan penekanan yang berlebihan yang kemudian menimbulkan nyeri menjalar. ${ }^{16}$

Peneliti berasumsi bahwa terdapat hubungan antara ketegangan saraf dengan pergerakan lingkup gerak sendi pada cervical. Penjelasan mengenai bagaimana upper limb neurodynamic dapat meningkatkan ROM cervical adalah secara mekanisme tidak langsung (indirect mechanism). Mekanisme tidak langsung tersebut terjadi oleh karena penurunan respon sensoris selama pemberian maneuver neurodynamic yang pada umumnya timbul ketika melakukan gerakan cervical.

Asumsi ini diperkuat oleh penelitian yang dilakukan oleh Joshi et al menjelaskan fenomena ini dalam studi nya mengenai respon normal dan pengaruhnya terhadap ROM cervical selama pelaksanaan neurodynamic testing. ${ }^{17}$ Dalam studi tersebut diketahui bahwa ROM cervical cenderung mengalami penurunan $(70,26 \pm 11,46$ menjadi $62,75 \pm 10,45)$ saat dilakukan pada posisi neurodynamic tension melalui dorsofleksi ankle. Secara tak langsung, struktur saraf dapat menjadi hambatan pergerakan cervical oleh karena kemampuan saraf menerima pembebanan tension sehingga intervensi pada struktur saraf tersebut dapat memberikan beberapa manfaat. ${ }^{17}$ Namun studi tersebut belum dapat sepenuhnya menjelaskan hasil penelitian ini karena teknik tension yang digunakan lebih pada eksteremitas bawah bukan esktremitas atas yang di mana hal tersebut memiliki perbedaan dari aspek biomekanik saraf.

Di samping itu, peningkatan ROM cervical pada tiap kelompok juga dapat dihasilkan oleh efek intervensi yang didapatkan oleh ke dua kelompok secara seimbang yaitu intervensi microwave diathermy sebagai intervensi standar dan pre-interventional warmup dan juga pemberian traksi cervical sebagai prosedur awal sebelum pemberian upper limb neurodynamic. Peneliti meyakini bahwa ke dua intervensi tersebut juga memiliki pengaruh terhadap peningkatan ROM cervical sebelum dan setelah intervensi pada tiap kelompok. Besarnya pengaruh tersebut belum dapat diukur oleh peneliti yang di mana merupakan salah satu kelemahan dalam penelitian ini. Kemudian, pemberian intervensi awalan yang diberikan dengan dosis yang sama pada ke dua kelompok 
ini dapat menjelaskan mengapa perbedaan yang bermakna sebelum dan sesudah intervensi pada tiap kelompok tidak disertai dengan perbedaan yang signifikan jika dibandingkan antara Kelompok 1 dan Kelompok 2 dalam meningkatkan ROM cervical.

Adapun implikasi klinis nya adalah bahwa baik upper limb neurodynamic ipsilateral maupun bilateral dapat meningkatkan ROM cervical. Fisioterapis dapat memilih baik antara ke dua jenis terapi ini dalam meningkatkan ROM cervical karena tidak adanya perbedaan yang signifikan antara ke dua jenis terapi ini secara statistik maupun secara klinis. Fisioterapis juga harus mempertimbangkan pemberian intervensi awalan seperti microwave diathermy dalam penanganan pada kasus cervical radiculopathy.

Berdasarkan pembahasan tersebut dapat disimpulkan bahwa tidak terdapat perbedaan yang bermakna antara ke dua kelompok di mana upper limb neurodynamic bilateral tidak lebih meningkatkan ROM cervical jika dibandingkan dengan upper limb neurodynamic ipsilateral pada kasus cervical radiculopathy.

\section{Upper Limb Neurodynamic Bilateral Lebih Menurunkan Tension Nervus Medianus dibandingkan dengan Upper Limb Neurodynamic Ipsilateral pada Penderita Cervical Radiculopathy}

Berdasarkan hasil penelitian ini, maka dapat diketahui bahwa ke dua intervensi neurodynamic ini dapat menurunkan tension nervus medianus yang diukur melalui ROM ekstensi elbow, namun upper limb neurodynamic bilateral menunjukkan peningkatkan ROM ekstensi elbow yang lebih besar jika dibandingkan dengan upper limb neurodynamic ipsilateral pada kasus cervical radiculopathy dan perbedaan tersebut terbukti signifikan secara statistik.

Hasil penelitian ini didukung oleh penelitian yang dilakukan oleh Salian et al pada 60 sampel yang menyatakan bahwa pemberian neuordynamic pada sisi kontralateral atau yang juga disebut dengan bilateral neurodynamic dalam posisi slump dapat meningkatkan ROM ekstensi lutut jika dibandingkan dengan pemberian upper limb neurodynamic pada sisi ispilateral saja setelah 6 kali intervensi. Pada kondisi iritasi akut, pemberian neurodynamic pada sisi yang mengalami simptomatis cenderung dapat memprovokasi keluhan yang dialami pasien sehingga modifikasi pada sisi kontralateral dapat bermanfaat pada pasien tersebut. ${ }^{18}$

Gerakan ekstensi lutut memiliki prinsip yang sama dengan gerakan ekstensi siku, dimana gerakan ekstensi lutut dan siku menghasilkan ROM yang besar sehingga menghasilkan tension yang cukup tinggi saat maneuver neurodynamic. ${ }^{19,} 20$ Pada titik ini, pemberian intervensi neurodynamic pada sisi kontralateral lebih bermanfaat oleh karena neurodynamic pada sisi kontralateral ini mengurangi ketegangan (tension) pada akar saraf sehingga gerakan ekstensi elbow dapat dilakukan hingga akhir ROM. $^{4}$

Hasil penelitian ini juga sesuai dengan teori oleh Shaclock dalam bukunya yang menyebutkan bahwa gerakan neurodynamic pada sisi kontralateral (bilateral neurodynamic) menyebabkan medulla spinalis bergerak pada komponen vertikalnya yaitu ke arah distal. Gerakan ke arah distal pada medulla spinalis ini menyebabkan panjang akar saraf pada sisi kiri (ipsilateral) berkurang sekitar $10 \%$ dan memiliki ketegangan (tension) yang lebih rendah daripada akar saraf pada yang diberikan teknik tension pada sisi ipsilateral. ${ }^{4}$

Kemudian, Salian dalam hasil penelitian yang berikutnya juga mendukung hasil penelitian ini dengan membuktikan efektivitas dari pemberian neurodynamic kontralateral terhadap ekstensibilitas nervus medianus pada pasien yang terdiagnosis cervical radiculopathy. 30 pasien yang mendapatkan 6 kali intervensi menunjukkan hasil yang signfikan terhadap peningkatan ROM elbow $(39,3 \pm 14,55$ menjadi 79,33 $\pm 9,14$ dengan $\mathrm{p}=0,00) .{ }^{9} \quad$ Namun, tidak adanya Kelompok Kontrol pada studi ini belum dapat menunjukkan perbandingan efektivitas jika dibandingkan dengan neurodynamic ipsilateral. 
Merujuk kembali pada penelitian oleh Byl yang betujuan untuk mengukur ketegangan (tension) saraf medianus dan saraf ulnaris yang dipengaruhi oleh posisi ekstremitas atas pada sisi kontralateral untuk mengevaluasi disfungsi saraf yaitu tension dysfunction. Hasil penelitian tersebut mendukung hipotesis penelitian ini yang menyatakan bahwa modifikasi posisi ekstremitas atas pada sisi kontralateral dapat mengubah status ketegangan saraf selama evaluasi disfungsi saraf melalui neurodynamic testing dengan karakteristik berkurangnya rasa nyeri saat dilukan ekstensi elbow. ${ }^{21}$

Hasil penelitian ini juga didukung oleh studi eksperimental yang dilakukan Sharma et al terhadap 100 sampel sehat untuk melihat efek perubahan posisi lengan pada sisi kontralateral pada ULNT 1 dengan cara mengukur ROM pada ekstensi elbow. ${ }^{22}$ Hasil studi eksperimental ini menunjukkan bahwa adanya perbedaan yang bermakna antara sensitivitas saraf medianus ketika lengan kontralateral berada dalam posisi netral jika dibandingkan dengan posisi ULNT dan tidak terdapat perbedaan yang bermakna pada sensitivitas saraf medianus ketika lengan kontralateral berada dalam posisi netral dan adduksi. ${ }^{22}$ Namun, hasil penelitian dari Sharma et al belum bisa sepenuhnya mendukung hasil dari studi ini oleh karena studi tersebut menggunakan sampel sehat yang cenderung mempengaruhi perbedaan hasil intervensi.

Berdasarkan kajian-kajian di atas, peneliti menyimpulkan bahwa peningkatan ROM ekstensi elbow yang lebih bermakna disebabkan oleh karna perubahan ketegangan nervus medianus yang cenderung berkurang saat pemberian upper limb neurodynamic pada sisi kontralateral. Gerakan ekstensi elbow saat dilakukannya ULNT memberikan tension yang berlebihan pada nervus medianus yang berujung kepada terbatasnya gerakan ekstensi elbow. Dengan menurunkan status ketegangan nervus medianus pada saat dilakukannya upper limb neurodynamic secara bilateral, maka gerakan ekstensi elbow dapat semakin ditingkatkan.
Berdasarkan pembahasan di atas, baik ipsilateral neurodynamic dan bilateral neurodynamic ke duanya dapat menghasilkan peningkatan ekskursi pada saraf medianus yang cenderung mengalami penjebakan oleh jaringan sekitarnya ${ }^{4}$ sehingga ke dua teknik intervensi ini baik dalam memperbaiki lingkup gerak sendi elbow yang menggambarkan fungsi ekskursi pada struktur saraf terhadap jaringan sekitarnya. Namun dapat disimpulkan bahwa, bilateral neurodynamic lebih baik dalam mendisipasi tension pada akar saraf secara lebih spesifik dan membawanya di sepanjang medulla spinalis secara merata, sehingga tidak menghasilkan tension yang berlebihan pada akar saraf yang cenderung memprovokasi keluhan yang dialami oleh pasien. ${ }^{4,5,18,22}$

\section{KETERBATASAN PENELITIAN}

1. Jumlah sampel dalam penelitian ini masih tergolong sedikit untuk sebuah randomized clinical trial sehingga hasil dari penelitian ini masih belum dapat digeneralisasikan dengan baik terhadap populasi.

2. Penelitian ini belum menggolongkan sampel yang mengalami cervical radiculopathy secara lebih spesifik berdasarkan tingkatannya, sehingga sampel memiliki tingkatan keluhan yang relatif bervariasi. Hal ini berdampak kepada penyetaraan outcome dari intervensi. Di samping hal tersebut, sebagian besar sampel didiagnosis mengalami cervical radiculopathy berdasarkan gejala klinis saja.

3. Terdapat beberapa beberapa variabel yang dapat berdampak terhadap hasil penelitian namun belum dapat terkontrol seperti aktivitas fisik dan tingkat kebugaran, pola hidup serta kebiasaan yang dilakukan oleh sampel, kepatuhan sampel dalam mengikuti jadwal intervensi fisioterapi, serta pekerjaan yang dimiliki oleh sampel. 
4. Peneltian ini tidak menggunakan kelompok kontrol yang tidak mendapatkan intervensi baik upper limb neurodynamic ipsilateral maupun bilateral. Oleh karena hal tersebut, peneliti belum dapat mengukur efek salah satu intervensi standar yang diberikan pada ke dua kelompok yaitu microwave diathermy terhadap penurunan nyeri, peningkatan ROM cervical, serta ROM ekstensi elbow dalam penelitian ini.

5. Pengukuran outcome pada penelitian ini dilakukan pada saat sebelum perlakuan (pretest), setelah perlakuan ke 6 dan setelah perlakuan ke 12 (post-test). Oleh karena terbatasnya jumlah pengukuran yang dilakukan, hasil dari penelitian ini belum dapat menjabarkan secara spesifik terhadap perubahan tingkat nyeri dan ROM cervical serta ekstensi elbow pada setiap akhir perlakuan sehingga belum diketahui apakah ke dua intervensi ini dapat memberikan perubahan jangka pendek (short-term effect).

6. Pengukuran skor nyeri, ROM cervical, serta ekstensi elbow yang terakhir dilakukan setelah 12 kali perlakuan dan belum dilakukannya follow-up yang berkelanjutan terhadap sampel setelah pemberian perlakuan berakhir. Oleh sebab itu, penelitian ini belum dapat menjelaskan terkait dengan efek jangka panjang (long-term effect) dari ke dua perlakuan tersebut terhadap penurunan nyeri serta penigkatan ROM cervical dan ekstensi elbow dalam kasus ini.

\section{DAFTAR PUSTAKA}

1. North American Spine Society. 2010. Evidence-based Clinical Guidelines for Multidisciplinary Spine Care-Diagnosis and treatment of Cervical Radiculopathy from Degenerative Disorders.

2. Iyer, M, and HJ Kim. 2016. "Cervical Radiculopathy." Curr Rev Musculoskeletal Med 9: 272-280.
3. Woods B, Hilibrand AS. 2015. Cervical radiculopathy: epidemiology, etiology, diagnosis, and treatment. J Spinal Disord Tech. 28: 251-259.

4. Shacklock M, Clinical neurodynamics, a new system for musculoskeletal system, Elsevier, Butterworth, Heinmann, 2005.

5. Wolny T, Saulicz E, Linek P, Shaclock M, Myliswiec A. 2017. Efficacy of Manual Therapy Including Neurodynamic Techniques for the Treatment of Carpal Tunnel Syndrome: A Randomized Controlled Trial. J Manipulative Physio Ther. 40(4): 263-272

6. Kim, HJ, VM Neman, C Piyaskulkaew, Vargas SR, and KD Riew. 2016. "Cervical Radiculopathy: Incidence and Treatment of 1420 Consecutive Case." Asian Spine Journal 231-237.

7. Rao R. 2002. Neck Pain, Cervical Radiculopathy, and Cervical Myelopathy. Pathophysiology, Natural History, and Clinical Evaluation. J Bone Joint Surg Am. 84: 1872-1881

8. Sheng B, Feng C, Zhang D, Spitler H, Shi L. 2017. Associations between Obesity and Spinal Disease: A Medical Expenditure Panel Study. Int.J.Environ.Res.Public Health. 14. 183

9. Salian SC, Sachdeva ND. 2018. Efficacy of contra-lateral neurodynamics on median nerve extensibility in cervical radiculopathy patients. International Journal of Medical and Health Research. 4(4): 47-52

10. Lohman, C. M., Gilbert, K. K., Sobczak, S., Brismée, J.-M., James, C. R., Day, M., Sizer, P. J. 2015 Young Investigator Award Winner: Cervical Nerve Root Displacement and Strain During Upper Limb Neural Tension Testing: Part 1: A Minimally Invasive Assessment in Unembalmed Cadavers. Spine, 40(11), 793-800.

11. Rade, M., Könönen, M., Vanninen, R., Marttila, J., Shacklock, M., Kankaanpää, 
M., \& Airaksinen, O. (2014). 2014 young investigator award winner: In vivo magnetic resonance imaging measurement of spinal cord displacement in the thoracolumbar region of asymptomatic subjects: part 2: comparison between unilateral and bilateral straight leg raise tests. Spine. 39(16), 1294-1300.

12. Nee RJ, Vincenzino B, Jull GA, Cleland JA, Coopieters MW: Neural tissue management provides immediate clinically relevant benefits without harmful effects for patients with nerve related neck and arm pain: a randomised trial. J Physiother 2012. 58(1):23-31

13. Kim DG, Chung SH, Jung HB. 2017. The Effect of Neural Mobilization on Cervical Radiculopathy patients Pain, Disability, ROM, and Deep Flexor Endurance. $J$ Back Musculoskelet Reabil. 30(5): 951959

14. Kumar KS, Kumar AK, Arjunan T, Thoufiq SK. 2017. The Effect of Neural Mobilization with Cervical Traction in Cervical Radiculopathy patients. JMSCR 5(5): 22078 - 22087

15. Savva C, Giakas G, Efsthathiou M, Karagiannis C, Mamais Ioannis. 2016. Effectiveness of neural mobilization with intermittent cervical traction in the management of cervical radiculopathy: A randomized controlled trial. International journal of osteopathic medicine. 21: 1929

16. Neumann DA. 2012. Kinesiology of the musculoskeetal system. Foundations for rehabilitation. Fourth edition. Missouri. Elsevier. Hal: 173-193

17. Joshi KC, Eapen C, Kumar S. 2013. Normal Sensory and Range of Motion (ROM) Response during Thoracic Slump Test (ST) in Asymptomatic Subjects. Journal of Manual \& Manipulative Therapy. 21(1): 24-32
18. Salian SC, Chaurasia S. 2016. Efficacy of Contra-lateral Neurodynamic Technique on Sciatic Nerve Extensibility in Young Asymptomatic Adults. International Journal of Current Advanced Research. 5(6): 1023-1027

19. Saini P, Arora B, Arora S. 2017. Effect of positioning of the contralateral lower limb on neurodynamics of straight leg raise test in subjects with low back pain. International Journal of Yoga, Physiotherapy and Physical Education. 2(5): 185-188

20. Nugraha MHS, Purnawati S, Irfan M, Handari-Adiputra LMIS, Muliarta IM, Wahyuddin. 2019. Kombinasi Pulsed Shortwave Therapy dan Neurodynamic Mobilization Lebih Efektif Menurunkan Disabilitas Punggung Dibandingkan Kombinasi Pulsed Shortwave Therapy Dan Lumbar Spine Stabilization Exercise Pada Pasien Hernia Nukleus Pulposus Lumbosakral. Sport and Fitness Journal. 7(1): 34-43

21. Byl C. and Puttlitz C. 2002. Strain in the median and ulnar nerves during upperextremity positioning. J. Hand Surg. 27(6): 1032-1040.

22. Sharma A, Arora M, Arora A. 2008. Effect of Different Positioning of Contralateral Arm on Upper Limb Neurodynamic Test (1). Physiotherapy and Occupational Therapy. 2(1): 107-111 